\title{
REVIEW
}

\section{A Review of Fluid Biomarkers for Alzheimer's Disease: Moving from CSF to Blood}

Kaj Blennow

Received: January 25, 2017

(C) The Author(s) 2017. This article is an open access publication

\begin{abstract}
A set of core cerebrospinal fluid (CSF) biomarkers for Alzheimer's disease (AD) includes total tau (T-tau), phosphorylated tau (P-tau) and $\beta$-amyloid 42 (A $\beta 42)$. These biomarkers reflect some of the key aspects of AD pathophysiology, including neuronal degeneration, tau phosphorylation with tangle formation, and $A \beta$ aggregation with deposition of the peptide into plaques. The core AD CSF biomarkers have been validated clinically in numerous studies, and found to have a very high diagnostic performance to identify $\mathrm{AD}$, both in the dementia and in the mild cognitive impairment stages of the disease. CSF A $\beta 42$ has also been found to show very high concordance with amyloid PET to identify brain amyloid deposition. The synaptic protein neurogranin is a novel candidate CSF biomarker for AD and prodromal AD. High CSF
\end{abstract}

Enhanced content To view enhanced content for this article go to http://www.medengine.com/Admin/ Project/NETHD1700008.

K. Blennow $(\bowtie)$

Department of Psychiatry and Neurochemistry, Institute of Neuroscience and Physiology, The Sahlgrenska Academy at University of Gothenburg, Mölndal, Sweden

e-mail: kaj.blennow@neuro.gu.se

K. Blennow

Clinical Neurochemistry Laboratory, Sahlgrenska

University Hospital, Mölndal, Sweden neurogranin predicts future cognitive decline and seems to be more specific for $\mathrm{AD}$ than, for example, T-tau. Importantly, technical developments have given ultrasensitive measurement techniques that allow measurement of brain-specific proteins such as tau and neurofilament light (NFL) in blood samples. Both plasma tau and NFL are increased in AD, and a recent study showed that plasma NFL has a diagnostic performance comparable to the core $\mathrm{AD}$ CSF biomarkers, and predicted future cognitive decline. Future large longitudinal clinical studies are warranted to determine the potential for plasma tau and NFL to serve as first-in-line screening tools for neurodegeneration in primary care.

Keywords: Alzheimer's disease; Biomarkers; Cerebrospinal fluid; $\beta$-Amyloid; Tau protein; Neurofilament light; Neurogranin

\section{INTRODUCTION}

Biomarkers for chronic neurodegenerative disorders such as Alzheimer's disease (AD) are of great importance, since the cognitive symptoms often are diffuse and overlap with other disorders; the clinical progression is slow and variable even between patients with the same disease. Biomarkers reflecting different types of pathophysiology in the brain can be used for 
clinical diagnosis, especially in the early stages of the disease, to predict progression, to monitor effects of novel drug candidates in clinical trials, and lastly also in clinical research to deepen our understanding of the pathogenesis of the disease [1]. In this context, the AD arena is in a good situation such that a set of highly validated and specific biomarkers are at hand. Imaging biomarkers for AD include amyloid and tau positron emission tomography (PET) to measure the amount of these protein deposits in the brain and magnetic resonance imaging (MRI) measurements of brain volume and neuronal connectivity. In addition, a set of cerebrospinal fluid (CSF) tests reflecting key aspects of disease pathology (neurodegeneration, tau pathology and amyloid deposits) are available. Laboratory medicine tests influence up to $70 \%$ of clinical decisions and thus have a central position in clinical medicine [2].

This paper comments on some caveats on the road to develop and validate these CSF biomarkers and some recent developments on novel biochemical tests.

\section{Compliance with Ethics Guidelines}

This article is based on previously conducted studies and does not involve any new studies of human or animal subjects performed by the author.

\section{THE CORE CSF BIOMARKERS FOR ALZHEIMER'S DISEASE}

The core AD CSF biomarkers include total tau (T-tau), phosphorylated tau (P-tau) and the 42 amino acid isoform (A $\beta 42$ ) of $\beta$-amyloid (Table 1 ). These analytes reflect key aspects of disease pathogenesis, i.e., neuronal and axonal degeneration, phosphorylation of tau with tangle formation, and oligomerization, aggregation and deposition of the $A \beta 42$ peptide into plaques [3].

The most commonly used technique to measure these $\mathrm{AD}$ biomarkers is the enzymelinked immunosorbent assay (ELISA), including an assay for T-tau that measures all tau isoforms irrespective of phosphorylation state [4], for tau phosphorylated at threonine 181 (P-tau181) [5], and for the 42 amino acid forms of $\beta$-amyloid (A $\beta 1-42)$ [6]. Numerous studies have very consistently found a marked increase in both T-tau and P-tau in $\mathrm{AD}$, accompanied by a decrease in CSF A $\beta 1-42$, as reviewed in a recent meta-analysis [7]. A high diagnostic performance of the core AD CSF biomarkers has also been validated in studies that confirmed diagnosis by autopsy. These studies showed better diagnostic performance of the CSF biomarkers than studies based on pure clinical diagnoses $[8,9]$.

Although the AD core CSF biomarkers have been well-validated clinically, a problem has been the variability in measurements between clinical laboratories, and over time between batches of reagents, which are more pronounced for $\mathrm{A} \beta 42$ than for T-tau or P-tau [10]. This problem stems from differences in analytical procedures for the manual ELISA methods between laboratories and from variability in reagent quality and manufacturing procedures for the kits. Standardization efforts to control for and resolve these issues include development of a fully validated mass spectrometry-based Reference Measurement Procedures (RMP) for CSF A $\beta 42$ to serve as the "gold standard" for A $\beta 42$ measurement [11], and Certified Reference Materials (CRM) for the core AD CSF biomarkers [12]. In addition, novel assays have been developed on fully automated laboratory analyzers, resulting in very precise and stable measurements, also between many reagents and laboratories [13]. These developments will provide the basis for validated and stable measurements of the AD CSF biomarker, and enable the introduction of uniform cut-off levels and a more general use of the CSF diagnostic in the routine clinical evaluation of patients with cognitive impairment and suspected AD.

\section{CSF Biomarkers for Early Diagnosis}

Mild cognitive impairment (MCI) is regarded as the earliest clinical phase of $\mathrm{AD}$, typically characterized by disturbances in episodic memory, although also disturbances in other cognitive domains may present early. However, $\mathrm{MCI}$ is a heterogeneous syndrome that may be caused by many disorders (only around half of 
Table 1 Cerebrospinal fluid and blood biomarkers for Alzheimer's disease

\begin{tabular}{|c|c|c|c|c|c|}
\hline Application & Fluid & Biomarker & Change in $\mathrm{AD}$ & Stage of development & Interpretation \\
\hline \multirow{13}{*}{$\begin{array}{l}\text { Core } \\
\text { biomarkers } \\
\text { for clinical } \\
\text { diagnostics }\end{array}$} & \multirow[t]{3}{*}{ CSF } & \multirow[t]{3}{*}{ T-tau } & $\begin{array}{l}\text { High T-tau is found in } \\
\text { AD and prodromal } \\
\text { AD }\end{array}$ & $\begin{array}{l}\text { Several validated } \\
\text { commercially available } \\
\text { immunoassays }\end{array}$ & $\begin{array}{l}\text { High } \mathrm{T} \text {-tau reflects intensity of } \\
\text { neurodegeneration and probably } \\
\text { reflects disease progression }\end{array}$ \\
\hline & & & $\begin{array}{l}\text { Mean change in } \mathrm{AD} \text { is to } \\
\text { around } 250 \% \text { of } \\
\text { age-matched controls }\end{array}$ & \multirow[t]{2}{*}{$\begin{array}{l}\text { Fully automated methods } \\
\text { are soon to be launched }\end{array}$} & \multirow[t]{2}{*}{$\begin{array}{l}\text { High T-tau is also found in some other } \\
\text { neurodegenerative (e.g., CJD) and } \\
\text { acute (e.g., stroke) brain disorders }\end{array}$} \\
\hline & & & $\begin{array}{l}\text { Sensitivity for } \mathrm{AD} \text { and } \\
\text { prodromal } \mathrm{AD}>90 \%\end{array}$ & & \\
\hline & \multirow[t]{3}{*}{ CSF } & \multirow[t]{3}{*}{ P-tau } & $\begin{array}{l}\text { High } \mathrm{P} \text {-tau is found in } \\
\mathrm{AD} \text { and prodromal } \\
\mathrm{AD}\end{array}$ & $\begin{array}{l}\text { Several validated } \\
\text { commercially available } \\
\text { immunoassays }\end{array}$ & $\begin{array}{l}\text { High P-tau reflects phosphorylation } \\
\text { state of tau and thus probably tau } \\
\text { pathology in } \mathrm{AD}\end{array}$ \\
\hline & & & $\begin{array}{l}\text { Mean change in } \mathrm{AD} \text { is to } \\
\text { around } 200 \% \text { of } \\
\text { age-matched controls }\end{array}$ & $\begin{array}{l}\text { Fully automated methods } \\
\text { are soon to be launched }\end{array}$ & \multirow{2}{*}{$\begin{array}{l}\text { P-tau is specific for AD than for T-tau; } \\
\text { high CSF levels have not been found } \\
\text { in other neurodegenerative disorders } \\
\text { and is not found in acute brain } \\
\text { disorders }\end{array}$} \\
\hline & & & $\begin{array}{l}\text { Sensitivity for AD and } \\
\text { prodromal AD }>90 \%\end{array}$ & & \\
\hline & \multirow[t]{4}{*}{ CSF } & \multirow[t]{4}{*}{$\mathrm{A} \beta 42$} & $\begin{array}{l}\text { Low } \mathrm{A} \beta 42 \text { is found in } \\
\mathrm{AD} \text { and prodromal } \\
\mathrm{AD}\end{array}$ & $\begin{array}{l}\text { Several validated } \\
\text { commercially available } \\
\text { immunoassays }\end{array}$ & $\begin{array}{l}\text { Low } \mathrm{A} \beta 42 \text { reflects brain amyloid } \\
\text { deposition, and show very high } \\
\text { concordance with amyloid PET }\end{array}$ \\
\hline & & & $\begin{array}{l}\text { Mean change in } \mathrm{AD} \text { is to } \\
\text { around } 50 \% \text { of } \\
\text { age-matched controls }\end{array}$ & $\begin{array}{l}\text { Two fully validated mass } \\
\text { spectrometry Reference } \\
\text { Measurement }\end{array}$ & \multirow[t]{3}{*}{$\begin{array}{l}\text { Low } \mathrm{A} \beta 42 \text { may be earlier during the } \\
\text { course of } \mathrm{AD} \text { than amyloid PET }\end{array}$} \\
\hline & & & $\begin{array}{l}\text { Sensitivity for } \mathrm{AD} \text { and } \\
\text { prodromal } \mathrm{AD}>90 \%\end{array}$ & $\begin{array}{l}\text { Procedures (RMP) } \\
\text { approved }\end{array}$ & \\
\hline & & & & $\begin{array}{l}\text { Fully automated methods } \\
\text { are soon to be launched }\end{array}$ & \\
\hline & \multirow[t]{3}{*}{ CSF } & \multirow[t]{3}{*}{$\mathrm{A} \beta 42 / \mathrm{A} \beta 40$} & $\begin{array}{l}\text { Low } A \beta 42 / A \beta 40 \text { ratio is } \\
\text { found in } \mathrm{AD} \text { and } \\
\text { prodromal } \mathrm{AD}\end{array}$ & $\begin{array}{l}\text { Several validated } \\
\text { commercially available } \\
\text { immunoassays }\end{array}$ & \multirow[t]{3}{*}{$\begin{array}{l}\text { The } A \beta 42 / A \beta 40 \text { ratio is thought to } \\
\text { compensate for between-individual } \\
\text { variations in "total" } \mathrm{A} \beta \text { production }\end{array}$} \\
\hline & & & $\begin{array}{l}\text { Mean change in } \mathrm{AD} \text { is to } \\
\text { around } 50 \% \text { of } \\
\text { age-matched controls }\end{array}$ & $\begin{array}{l}\text { Fully automated methods } \\
\text { are soon to be launched }\end{array}$ & \\
\hline & & & $\begin{array}{l}\text { Sensitivity and specificity } \\
\text { is higher than for } A \beta 42 \\
\text { alone }\end{array}$ & & \\
\hline \multirow{2}{*}{$\begin{array}{l}\text { Candidate } \\
\text { diagnostic } \\
\text { biomarker }\end{array}$} & \multirow[t]{2}{*}{ CSF } & \multirow[t]{2}{*}{ Neurogranin } & \multirow{2}{*}{$\begin{array}{l}\text { High neurogranin is } \\
\text { found in } \mathrm{AD} \text { and } \\
\text { prodromal } \mathrm{AD}\end{array}$} & \multirow{2}{*}{$\begin{array}{l}\text { Several research grade } \\
\text { assays have been } \\
\text { published }\end{array}$} & $\begin{array}{l}\text { High neurogranin reflects synaptic } \\
\text { dysfunction or degeneration }\end{array}$ \\
\hline & & & & & $\begin{array}{l}\text { Increased neurogranin may be specific } \\
\text { for } \mathrm{AD}\end{array}$ \\
\hline \multirow{3}{*}{$\begin{array}{l}\text { Candidate } \\
\text { screening } \\
\text { tools }\end{array}$} & \multirow[t]{2}{*}{ Blood } & \multirow[t]{2}{*}{ Tau } & \multirow{2}{*}{$\begin{array}{l}\text { High plasma tau is found } \\
\text { in } \mathrm{AD} \text { and prodromal } \\
\mathrm{AD} \text {, but with overlap } \\
\text { between groups }\end{array}$} & $\begin{array}{l}\text { Several research grade } \\
\text { assays published }\end{array}$ & \multirow{2}{*}{$\begin{array}{l}\text { High plasma tau is a general biomarker } \\
\text { for neurodegeneration, and not } \\
\text { specific for AD }\end{array}$} \\
\hline & & & & $\begin{array}{l}\text { One commercially } \\
\text { available immunoassay }\end{array}$ & \\
\hline & Blood & NFL & $\begin{array}{l}\text { High plasma NFL is } \\
\text { found in } \mathrm{AD} \text { and } \\
\text { prodromal } \mathrm{AD} \text {, but } \\
\text { with overlap between } \\
\text { groups }\end{array}$ & $\begin{array}{l}\text { One validated research } \\
\text { grade assay published } \\
\text { One commercially } \\
\text { available immunoassay }\end{array}$ & $\begin{array}{l}\text { High plasma NFL is a general } \\
\text { biomarker for neurodegeneration, } \\
\text { and not specific for AD }\end{array}$ \\
\hline
\end{tabular}

$A \beta$ amyloid- $\beta, A D$ Alzheimer disease, CJD Creutzfeldt-Jakob disease, CSF cerebrospinal fluid, NFL neurofilament light, $P E T$ positron emission tomography, $P$-tau phosphorylated tau, T-tau total tau 
cases have $\mathrm{AD}$ ), which introduces obvious diagnostic difficulties. At the same time, treatment with disease-modifying agents will likely be most effective in this stage of $\mathrm{AD}$, or even pre-clinically, before neurodegeneration is too severe and widespread. Thus, studies examining the potential of the AD CSF biomarkers for early diagnosis were warranted. The first was published in 1999, by Andreasen and co-workers, and showed that MCI patients who progress to $\mathrm{AD}$ with dementia during clinical follow-up have the typical AD CSF biomarker profile (decreased CSF A $\beta 42$ together with increased T-tau and P-tau) already in this stage of the disease [14]. Importantly, the CSF biomarkers were stable at follow-up when patients had reached the dementia stage, indicating that these biomarkers do not change during the clinical stages of the disease [14].

An extended clinical follow-up period is needed to ascertain which MCI will not progress to dementia, or even will improve so that they no longer have memory problems. The first study with such extended clinical follow-up was published in 2006 by Hansson and co-workers [15]. This study showed cognitively stable MCI patients do not have the $\mathrm{AD}$ biomarker profile, while progressive MCI patients (with prodromal AD) could be identified with $95 \%$ sensitivity and $92 \%$ specificity against elderly controls and 83\% specificity against stable MCI cases [15]. This very high diagnostic accuracy for the core AD CSF biomarkers for prodromal AD was later verified in several large multi-center studies, including the DESCRIPA study in Europe [16], the American ADNI study [9], and the Swedish Brain Power study [17]. Taken together, these, and several subsequent studies, support that the $\mathrm{AD}$ core CSF biomarker profile has diagnostic value to identify $\mathrm{MCI}$ prodromal $\mathrm{AD}$ cases in unselected MCI populations.

\section{BIOMARKER-BASED DIAGNOSTIC RESEARCH CRITERIA FOR AD}

Recent reports show promise that we may have disease-modifying drugs for $\mathrm{AD}$ in the near future. For example, $\beta$-secretase (BACE1) inhibitors show a marked, dose-dependent, reduction in brain and CSF A $\beta$ levels [18], which may translate into effects on brain $A \beta$ aggregation, plaque formation and a beneficial effect on clinical disease progression. Furthermore, the Phase $1 b$ aducanumab trial showed a doseand time-dependent reduction in brain amyloid plaques as measured by florbetapir PET, but also a high frequency of amyloid-related imaging abnormalities (ARIA) [19].

Thus, given that we may soon have effective, but most likely also expensive, drugs that may give side-effects such as ARIA, and that mild cognitive impairment (MCI) is a heterogeneous syndrome caused by many disorders (only around half of cases have AD), there is a large need for biomarker-based diagnostic criteria that allow an accurate diagnosis of $\mathrm{AD}$ already during the MCI stage, for review see [20]. The first such criteria were published in 2007, Dubois and co-workers presented novel research criteria for the diagnosis of prodromal $\mathrm{AD}$, i.e., before the dementia stage, which are based on clinical core of early and significant episodic memory impairment together with at least one or more abnormal biomarkers among structural neuroimaging with MRI, molecular neuroimaging with PET, and CSF analyses of amyloid $\beta$ and tau protein [21]. A revised and updated version of these criteria was published in 2014, the main difference being that downstream topographical biomarkers (volumetric MRI and FDG-PET), were not included among core diagnostic biomarkers (now restricted to amyloid PET and the CSF biomarkers) but only used for monitoring disease course or stage [22].

Since two amyloid biomarkers are included in the updated International Working Group (IWG-2) criteria [22], there is a need to understand if they give complementary information, or if they can be used interchangeably. A meta-analysis show very high concordance between CSF A 342 concentrations (measured using different assay formats) and amyloid PET (several different ligands) for classifying cases as being either brain amyloid positive or negative [23]. For example, a study using CSF A $\beta 42$ measurements in clinical routine during two years compared concordance with ${ }^{18}$ F-flutemetamol amyloid PET in an unselected cohort of patients with memory complaints, 
and found a concordance (both CSF A $\beta 42$ and amyloid PET being either positive or negative) of $92-97 \%$ [24]. Furthermore, a study based on the ADNI-2 cohort showed CSF A 342 alone gives the same diagnostic accuracy for prodromal AD or AD dementia as either global amyloid PET scores or regional (temporal, parietal, frontal or cingulate) SUVr evaluations [25]. These findings suggest that CSF A $\beta 42$ and amyloid PET may be used interchangeably, and that regional PET assessments do not add to diagnostic accuracy.

However, the most common variant of discordance is cases being positive for CSF A $\beta 42$ but have negative amyloid PET scans [23]. One study examining the reason for this in more detail showed that discordancy is much more common in cognitively normal elderly and early MCI cases than in late MCI and $\mathrm{AD}$ dementia cases [26]. Furthermore, a recent study showed that non-demented elderly who are CSF A $\beta 42$ positive but amyloid PET negative builds up amyloid deposits in the brain to the same degree as cases who are positive for both biomarkers [27]. Taken together, these data suggest that CSF A 42 detects cortical amyloid accumulation earlier than amyloid PET. This knowledge may be important in the clinical decision whether to perform CSF analysis or amyloid PET in patients with mild memory complaints and suspected early AD pathology. Lastly, while amyloid PET gives a static estimate of the amount of brain amyloid deposits, the addition of CSF T-tau and P-tau (to CSF A $\beta 42$ measurements) will provide an estimation on the rate of future cognitive decline and thus prognosis $[28,29]$.

\section{NOVEL BIOMARKERS FOR SYNAPTIC DYSFUNCTION AND DEGENERATION}

While we have well-validated CSF biomarkers for neurodegeneration as well as plaque and tangle pathology, there is no established or validated biomarker test for synaptic dysfunction or degeneration that is a key feature of AD pathophysiology. Synaptic degeneration and loss is one of the best pathoanatomical correlates of cognitive deficits in $\mathrm{AD}$ and predicts disease better than $\mathrm{A} \beta$ plaque load $[30,31]$. Several potential pathogenic mechanisms have been proposed to cause synaptic dysfunction with dendritic spine loss in $A D$, including $A \beta$ fibrils [32], diffusible $A \beta$ oligomers [33], intracellular $A \beta$ accumulation [34], but also tau hyperphosphorylation and activation of microglia [35, 36].

It is clear that reliable biomarkers to monitor synaptic and dendritic function and loss directly in AD patients and cognitively normal elderly would be a very valuable addition to the $\mathrm{AD}$ diagnostic biomarker toolbox, but also in clinical trials to monitor pharmacodynamic effects of novel drug candidates on synaptic dysfunction and degeneration.

Neurogranin is a dendritic protein expressed in the cortex and hippocampus by excitatory neurons [37, 38], and has a key role in synaptic plasticity and induction of long-term potentiation (LTP) in the hippocampus $[39,40]$. In the normal human brain, $\mathrm{Ng}$ expression is highest in associative cortical areas, while in $\mathrm{AD}$, neurogranin levels are in the cortex and hippocampus $[41,42]$ reflecting the synaptic loss. Thus, measurement of neurogranin in CSF may give a biomarker reflecting dendritic instability and degeneration and thereby serve as the direct link to clinical symptoms in AD (Table 1).

In 1999, we showed that a number of synaptic proteins, including neurogranin, are secreted to the CSF [41]. A first pilot study using immunoprecipitation combined with Western blotting to evaluate CSF neurogranin as an $\mathrm{AD}$ biomarker showed a marked increase in $\mathrm{AD}$ as compared with controls [43]. After developing novel monoclonal antibodies to measure neurogranin by ELISA, high CSF levels were found to predict prodromal AD in MCI [44]. High CSF neurogranin in $\mathrm{AD}$ dementia and prodromal $\mathrm{AD}$ has been confirmed in several subsequent papers $[45,46]$, including in the ADNI study [47]. High CSF neurogranin also correlates with the future rate of hippocampal trophy measured by MRI and rate of metabolic reductions on FDG-PET [47]. Interestingly, a recent study suggests that high CSF neurogranin may be specific for $\mathrm{AD}$, and not found in other neurodegenerative disorders such as 
frontotemporal dementia, Lewy body dementia, Parkinson disease, progressive supranuclear palsy, or multiple system atrophy [48].

Mass spectrometry characterization of neurogranin in CSF suggests that it is present in CSF as a series of C-terminal peptides [44], while a study combining immunoprecipitation and Western blotting identify a band in CSF corresponding to the full-length protein [43]. A study using an immunoassay based on combining Nand C-terminal neurogranin antibodies in a sandwich format, which in theory measures full-length neurogranin, also found high CSF levels in $\mathrm{AD}$ and $\mathrm{MCI}$ as compared with controls [49]. Thus, we need further studies on in which way neurogranin is processed before being released to the CSF, including studies comparing the diagnostic potential of full-length versus C-terminal neurogranin peptides.

\section{BLOOD BIOMARKERS: THE HOLY GRAIL IN THE AD BIOMARKER ARENA}

Both imaging biomarkers (PET imaging of amyloid and tau aggregates) and CSF measurement of amyloid and tau work well to identify AD pathophysiology. However, PET imaging is very expensive and only accessible in specialized centers, and thus unlikely to be a routine diagnostic tool in the assessment of the very high number of patients seeking medical advice for cognitive symptoms. Further, even if CSF collection is routine in clinical neurology, and the cost for the $\mathrm{AD}$ CSF biomarker tests are much lower than for EPT scans, lumbar puncture may be regarded as complicated, time-consuming and invasive by many clinicians. Thus, measurement of biomarkers in blood samples would be a more practical approach.

However, a major challenge in developing blood biomarkers is that brain-specific proteins reflect $\mathrm{AD}$ molecular mechanisms at much lower concentrations in blood than in CSF. As an example, the CSF level of the neuronal protein tau is around $2-300 \mathrm{pg} / \mathrm{mL}$ [50], while the plasma level is 100 times lower, around $5 \mathrm{pg} / \mathrm{mL}$ [51]. Except for requirements regarding analytical sensitivity, these very low levels must be quantified within a matrix of other proteins (e.g., albumin and immunoglobulins) that are 10 billion times higher [52]. Importantly, technological developments have given ultrasensitive measurement techniques, such as the immuno-magnetic reduction (IMR) and Single-molecule array (Simoa) methods, that allow accurate analyses of biomarkers in blood samples [53].

Increased tau levels in plasma in $\mathrm{AD}$ has been found using both the IMR [54], and Simoa [51], methods. A recent study on the large ADNI and BIOFINDER cohorts confirmed an increase in plasma tau in AD dementia, although with a large overlap in levels with controls [55]. Further, longitudinal data from the analysis in ADNI showed significant associations between plasma tau and worse cognition, more atrophy, and more hypometabolism during follow-up. Longitudinal analyses in ADNI showed that higher plasma tau predicts future rate of cognitive decline, increases in brain atrophy measured by MRI, and reductions of more cortical glucose metabolism examined by FDG-PET [55].

While plasma and CSF tau levels correlate poorly [55], the correlation is very tight between plasma and CSF neurofilament light (NFL) protein [56], another axonal neuron-specific protein. Blood (serum or plasma) NFL can be accurately measured by an immunoassay developed on the Simoa platform [57]. The Simoa assay has 25- to 125 -fold better analytical sensitivity than when the same anti-NFL antibodies are used in immunoassays based on the electrochemiluminescence (ECL) Meso Scale Diagnostics (MSD) technique or standard ELISA [57], meaning that NFL can be measured also in blood samples from normal individuals, which are below the level for accurate quantification when using ECL-MSD or ELISA methods.

Using the Simoa NFL assay, a recent study on the large ADNI cohort showed a marked increase in plasma NFL in AD and MCI patients as compared with controls, with a diagnostic performance comparable to the core AD CSF biomarkers [58]. Further, plasma NFL was highest in $\mathrm{AD}$ and $\mathrm{MCI}$ cases with positive amyloid PET scans, and correlated with poorer cognition and higher rate of future brain atrophy (measured by MRI) and hypometabolism as 
measured by FDG-PET [58]. However, high plasma levels of NFL are also found in several other neurodegenerative disorders such as FTD and PSP $[59,60]$.

A possible future application for plasma tau and NFL is in the clinical evaluation of patients with cognitive disturbances in primary care. Here, plasma tau and NFL may serve as simple, non-invasive, and cheap screening tools to identify, or rule out, neurodegeneration. However, future large longitudinal studies are needed to determine the cut-off for positivity and the sensitivity and specificity to identify AD.

\section{ACKNOWLEDGEMENTS}

The work was supported by Grants from the Swedish Research Council, the Torsten Söderberg Foundation and the Swedish Alzheimer's Association. No funding was received for the publication of this article. All named authors meet the International Committee of Medical Journal Editors (ICMJE) criteria for authorship for this manuscript, take responsibility for the integrity of the work as a whole, and have given final approval for the version to be published.

Disclosures. Dr. Blennow has served on advisory boards or as a consultant for Eli-Lilly, Fujirebio Europe, IBL International, and Roche Diagnostics, has got travel support from MagQu Co. Ltd., Taiwan, and is a co-founder of Brain Biomarker Solutions in Gothenburg AB, a GU Holding-based platform company at the University of Gothenburg.

Compliance with Ethics Guidelines. This article is based on previously conducted studies and does not involve any new studies of human or animal subjects performed by the author.

Open Access. This article is distributed under the terms of the Creative Commons Attribution-NonCommercial 4.0 International License (http://creativecommons.org/licenses/ by-nc/4.0/), which permits any noncommercial use, distribution, and reproduction in any medium, provided you give appropriate credit to the original author(s) and the source, provide a link to the Creative Commons license, and indicate if changes were made.

\section{REFERENCES}

1. Blennow $\mathrm{K}$, Hampel $\mathrm{H}$, Weiner $\mathrm{M}$, Zetterberg $\mathrm{H}$. Cerebrospinal fluid and plasma biomarkers in Alzheimer disease. Nat Rev Neurol. 2010;6(3):131-44.

2. Beastall GH, Watson ID. Clinical Chemistry and Laboratory Medicine: an appreciation. Clin Chem Lab Med CCLM/FESCC. 2013;51(1):3-4.

3. Blennow K, Hampel H. CSF markers for incipient Alzheimer's disease. Lancet Neurol. 2003;2(10):605-13.

4. Blennow K, Wallin A, Agren H, Spenger C, Siegfried $\mathrm{J}$, Vanmechelen E. Tau protein in cerebrospinal fluid: a biochemical marker for axonal degeneration in Alzheimer disease? Mol Chem Neuropathol. $1995 ; 26(3): 231-45$.

5. Vanmechelen E, Vanderstichele $\mathrm{H}$, Davidsson $\mathrm{P}$, Van Kerschaver E, Van Der Perre B, Sjogren M, et al. Quantification of tau phosphorylated at threonine 181 in human cerebrospinal fluid: a sandwich ELISA with a synthetic phosphopeptide for standardization. Neurosci Lett. 2000;285(1):49-52.

6. Andreasen N, Minthon L, Clarberg A, Davidsson P, Gottfries J, Vanmechelen E, et al. Sensitivity, specificity, and stability of CSF-tau in AD in a community-based patient sample. Neurology. 1999;53(7):1488-94.

7. Olsson B, Lautner R, Andreasson U, Ohrfelt A, Portelius E, Bjerke $\mathrm{M}$, et al. CSF and blood biomarkers for the diagnosis of Alzheimer's disease: a systematic review and meta-analysis. Lancet Neurol. 2016;15(7):673-84.

8. Koopman K, Le Bastard N, Martin JJ, Nagels G, De Deyn PP, Engelborghs S. Improved discrimination of autopsy-confirmed Alzheimer's disease (AD) from non-AD dementias using CSF P-tau (181P). Neurochem Int. 2009;55(4):214-8.

9. Shaw LM, Vanderstichele H, Knapik-Czajka M, Clark CM, Aisen PS, Petersen RC, et al. Cerebrospinal fluid biomarker signature in Alzheimer's disease neuroimaging initiative subjects. Ann Neurol. 2009;65(4):403-13.

10. Mattsson N, Andreasson U, Persson S, Arai H, Batish $\mathrm{SD}$, Bernardini S, et al. The Alzheimer's Association external quality control program for cerebrospinal 
fluid biomarkers. Alzheimers Dement J Alzheimers Assoc. 2011;7(4):386-95 (e6).

11. Leinenbach A, Pannee J, Dulffer T, Huber A, Bittner $\mathrm{T}$, Andreasson $\mathrm{U}$, et al. Mass spectrometry-based candidate reference measurement procedure for quantification of amyloid-beta in cerebrospinal fluid. Clin Chem. 2014;60(7):987-94.

12. Kuhlmann J, Andreasson U, Pannee J, Bjerke M, Portelius E, Leinenbach A, et al. CSF Abeta1-42-an excellent but complicated Alzheimer's biomarker: a route to standardisation. Clin Chim Acta. 2017;467:27-33.

13. Bittner T, Zetterberg H, Teunissen CE, Ostlund RE Jr, Militello M, Andreasson U, et al. Technical performance of a novel, fully automated electrochemiluminescence immunoassay for the quantitation of beta-amyloid (1-42) in human cerebrospinal fluid. Alzheimers Dement. 2016;12(5):517-26.

14. Andreasen N, Minthon L, Vanmechelen E, Vanderstichele H, Davidsson P, Winblad B, et al. Cerebrospinal fluid tau and Abeta42 as predictors of development of Alzheimer's disease in patients with mild cognitive impairment. Neurosci Lett. 1999;273(1):5-8.

15. Hansson O, Zetterberg H, Buchhave $\mathrm{P}$, Londos E, Blennow K, Minthon L. Association between CSF biomarkers and incipient Alzheimer's disease in patients with mild cognitive impairment: a follow-up study. Lancet Neurol. 2006;5(3):228-34.

16. Visser PJ, Verhey F, Knol DL, Scheltens P, Wahlund LO, Freund-Levi Y, et al. Prevalence and prognostic value of CSF markers of Alzheimer's disease pathology in patients with subjective cognitive impairment or mild cognitive impairment in the DESCRIPA study: a prospective cohort study. Lancet Neurol. 2009;8(7):619-27.

17. Mattsson N, Zetterberg H, Hansson O, Andreasen N, Parnetti L, Jonsson M, et al. CSF biomarkers and incipient Alzheimer disease in patients with mild cognitive impairment. JAMA J Am Med Assoc. 2009;302(4):385-93.

18. May PC, Willis BA, Lowe SL, Dean RA, Monk SA, Cocke PJ, et al. The potent BACE1 inhibitor LY2886721 elicits robust central Abeta pharmacodynamic responses in mice, dogs, and humans. J Neurosci. 2015;35(3):1199-210.

19. Sevigny J, Chiao P, Bussiere T, Weinreb PH, Williams L, Maier M, et al. The antibody aducanumab reduces Abeta plaques in Alzheimer's disease. Nature. 2016;537(7618):50-6.

20. Hampel H, Frank R, Broich K, Teipel SJ, Katz RG, Hardy J, et al. Biomarkers for Alzheimer's disease: academic, industry and regulatory perspectives. Nat Rev Drug Discov. 2010;9(7):560-74.

21. Dubois B, Feldman HH, Jacova C, Dekosky ST, Barberger-Gateau P, Cummings J, et al. Research criteria for the diagnosis of Alzheimer's disease: revising the NINCDS-ADRDA criteria. Lancet Neurol. 2007;6(8):734-46.

22. Dubois B, Feldman $\mathrm{HH}$, Jacova C, Hampel $\mathrm{H}$, Molinuevo JL, Blennow K, et al. Advancing research diagnostic criteria for Alzheimer's disease: the IWG-2 criteria. Lancet Neurol. 2014;13(6):614-29.

23. Blennow $\mathrm{K}$, Mattsson $\mathrm{N}$, Scholl M, Hansson O, Zetterberg H. Amyloid biomarkers in Alzheimer's disease. Trends Pharmacol Sci. 2015;36(5):297-309.

24. Palmqvist S, Zetterberg H, Blennow K, Vestberg S, Andreasson U, Brooks DJ, et al. Accuracy of brain amyloid detection in clinical practice using cerebrospinal fluid beta-amyloid 42: a cross-validation study against amyloid positron emission tomography. JAMA Neurol. 2014;71(10):1282-9.

25. Mattsson N, Insel PS, Landau S, Jagust W, Donohue M, Shaw LM, et al. Diagnostic accuracy of CSF Ab42 and florbetapir PET for Alzheimer's disease. Ann Clin Transl Neurol. 2014;1(8):534-43.

26. Mattsson N, Insel PS, Donohue M, Landau S, Jagust WJ, Shaw LM, et al. Independent information from cerebrospinal fluid amyloid-beta and florbetapir imaging in Alzheimer's disease. Brain. 2015;138(Pt 3):772-83.

27. Palmqvist $\mathrm{S}$, Zetterberg $\mathrm{H}$, Mattsson N, Johansson $\mathrm{P}$, Alzheimer's Disease Neuroimaging I, Minthon L, et al. Detailed comparison of amyloid PET and CSF biomarkers for identifying early Alzheimer disease. Neurology. 2015;85(14):1240-9.

28. Buchhave P, Minthon L, Zetterberg H, Wallin AK, Blennow K, Hansson O. Cerebrospinal fluid levels of beta-amyloid 1-42, but not of tau, are fully changed already 5-10 years before the onset of Alzheimer dementia. Arch Gen Psychiatry. 2012;69(1):98-106.

29. van Rossum IA, Vos SJ, Burns L, Knol DL, Scheltens $\mathrm{P}$, Soininen $\mathrm{H}$, et al. Injury markers predict time to dementia in subjects with MCI and amyloid pathology. Neurology. 2012;79(17):1809-16.

30. Terry RD, Masliah E, Salmon DP, Butters N, DeTeresa R, Hill R, et al. Physical basis of cognitive alterations in Alzheimer's disease: synapse loss is the major correlate of cognitive impairment. Ann Neurol. 1991;30(4):572-80.

31. DeKosky ST, Scheff SW. Synapse loss in frontal cortex biopsies in Alzheimer's disease: correlation 
with cognitive severity. Ann Neurol. 1990;27(5):457-64.

32. Bittner T, Burgold S, Dorostkar MM, Fuhrmann M, Wegenast-Braun BM, Schmidt B, et al. Amyloid plaque formation precedes dendritic spine loss. Acta Neuropathol. 2012;124(6):797-807.

33. Shankar GM, Bloodgood BL, Townsend M, Walsh DM, Selkoe DJ, Sabatini BL. Natural oligomers of the Alzheimer amyloid-beta protein induce reversible synapse loss by modulating an NMDA-type glutamate receptor-dependent signaling pathway. J Neurosci. 2007;27(11):2866-75.

34. Zou C, Montagna E, Shi Y, Peters F, Blazquez-Llorca L, Shi S, et al. Intraneuronal APP and extracellular Abeta independently cause dendritic spine pathology in transgenic mouse models of Alzheimer's disease. Acta Neuropathol. 2015;129(6):909-20.

35. Dickstein DL, Brautigam H, Stockton SD Jr, Schmeidler J, Hof PR. Changes in dendritic complexity and spine morphology in transgenic mice expressing human wild-type tau. Brain Struct Funct. 2010;214(2-3):161-79.

36. Bellucci A, Westwood AJ, Ingram E, Casamenti F, Goedert M, Spillantini MG. Induction of inflammatory mediators and microglial activation in mice transgenic for mutant human P301S tau protein. Am J Pathol. 2004;165(5):1643-52.

37. Represa A, Deloulme JC, Sensenbrenner M, Ben-Ari Y, Baudier J. Neurogranin: immunocytochemical localization of a brain-specific protein kinase C substrate. J Neurosci. 1990;10(12):3782-92.

38. Guadano-Ferraz A, Vinuela A, Oeding G, Bernal J, Rausell E. RC3/neurogranin is expressed in pyramidal neurons of motor and somatosensory cortex in normal and denervated monkeys. J Comp Neurol. 2005;493(4):554-70.

39. Fedorov NB, Pasinelli P, Oestreicher AB, DeGraan PN, Reymann KG. Antibodies to postsynaptic PKC substrate neurogranin prevent long-term potentiation in hippocampal CA1 neurons. Eur J Neurosci. 1995;7(4):819-22.

40. Chen SJ, Sweatt JD, Klann E. Enhanced phosphorylation of the postsynaptic protein kinase $C$ substrate RC3/neurogranin during long-term potentiation. Brain Res. 1997;749(2):181-7.

41. Davidsson P, Blennow K. Neurochemical dissection of synaptic pathology in Alzheimer's disease. Int Psychogeriatr IPA. 1998;10(1):11-23.

42. Reddy PH, Mani G, Park BS, Jacques J, Murdoch G, Whetsell W Jr, et al. Differential loss of synaptic proteins in Alzheimer's disease: implications for synaptic dysfunction. J Alzheimers Dis JAD. 2005;7(2):103-17 (discussion 73-80).

43. Thorsell A, Bjerke M, Gobom J, Brunhage E, Vanmechelen E, Andreasen N, et al. Neurogranin in cerebrospinal fluid as a marker of synaptic degeneration in Alzheimer's disease. Brain Res. 2010;1362:13-22.

44. Kvartsberg H, Duits FH, Ingelsson M, Andreasen N, Ohrfelt A, Andersson K, et al. Cerebrospinal fluid levels of the synaptic protein neurogranin correlates with cognitive decline in prodromal Alzheimer's disease. Alzheimers Dement. 2015;11(10):1180-90.

45. Hellwig K, Kvartsberg H, Portelius E, Andreasson U, Oberstein TJ, Lewczuk P, et al. Neurogranin and YKL-40: independent markers of synaptic degeneration and neuroinflammation in Alzheimer's disease. Alzheimers Res Ther. 2015;7:74.

46. Kvartsberg $\mathrm{H}$, Portelius E, Andreasson U, Brinkmalm G, Hellwig K, Lelental N, et al. Characterization of the postsynaptic protein neurogranin in paired cerebrospinal fluid and plasma samples from Alzheimer's disease patients and healthy controls. Alzheimers Res Ther. 2015;7(1):40.

47. Portelius E, Zetterberg H, Skillback T, Tornqvist U, Andreasson U, Trojanowski JQ, et al. Cerebrospinal fluid neurogranin: relation to cognition and neurodegeneration in Alzheimer's disease. Brain J Neurol. 2015;138(Pt 11):3373-85.

48. Wellington $\mathrm{H}$, Paterson RW, Portelius E, Tornqvist $\mathrm{U}$, Magdalinou N, Fox NC, et al. Increased CSF neurogranin concentration is specific to Alzheimer disease. Neurology. 2016;86(9):829-35.

49. Kester MI, Teunissen CE, Crimmins DL, Herries EM, Ladenson JH, Scheltens P, et al. Neurogranin, a CSF biomarker for synaptic loss, predicts decline to symptomatic Alzheimer disease. JAMA Neurol. 2015; (In press).

50. Sjogren $\mathrm{M}$, Vanderstichele $\mathrm{H}$, Agren $\mathrm{H}$, Zachrisson O, Edsbagge M, Wikkelso C, et al. Tau and Abeta42 in cerebrospinal fluid from healthy adults 2193 years of age: establishment of reference values. Clin Chem. 2001;47(10):1776-81.

51. Zetterberg H, Wilson D, Andreasson U, Minthon L, Blennow K, Randall J, et al. Plasma tau levels in Alzheimer's disease. Alzheimers Res Ther. 2013;5(2):9.

52. Blennow K, Fredman P, Wallin A, Gottfries CG, Karlsson I, Langstrom G, et al. Protein analysis in cerebrospinal fluid. II. Reference values derived from healthy individuals $18-88$ years of age. Eur Neurol. 1993;33(2):129-33. 
53. Andreasson U, Blennow K, Zetterberg H. Update on ultrasensitive technologies to facilitate research on blood biomarkers for central nervous system disorders. Alzheimers Dement (Amst). 2016;3:98-102.

54. Tzen KY, Yang SY, Chen TF, Cheng TW, Horng HE, Wen HP, et al. Plasma Abeta but not tau is related to brain $\mathrm{PiB}$ retention in early Alzheimer's disease. ACS Chem Neurosci. 2014;5(9):830-6.

55. Mattsson N, Zetterberg H, Janelidze S, Insel PS, Andreasson U, Stomrud E, et al. Plasma tau in Alzheimer disease. Neurology. 2016;87(17):1827-35.

56. Gisslen M, Price RW, Andreasson U, Norgren N, Nilsson S, Hagberg L, et al. Plasma concentration of the neurofilament light protein (NFL) is a biomarker of CNS injury in HIV infection: a cross-sectional study. EBioMedicine. 2016;3:135-40.

57. Kuhle J, Barro C, Andreasson U, Derfuss T, Lindberg $\mathrm{R}$, Sandelius A, et al. Comparison of three analytical platforms for quantification of the neurofilament light chain in blood samples: ELISA, electrochemiluminescence immunoassay and Simoa. Clin Chem Lab Med. 2016;54(10):1655-61.

58. Mattsson N, Andreasson U, Zetterberg H, Blennow K. Alzheimer's disease neuroimaging I. Association of plasma neurofilament light with neurodegeneration in patients with Alzheimer disease. JAMA Neurol. 2017;74:557-66.

59. Rohrer JD, Woollacott IO, Dick KM, Brotherhood E, Gordon E, Fellows A, et al. Serum neurofilament light chain protein is a measure of disease intensity in frontotemporal dementia. Neurology. 2016;87(13):1329-36.

60. Rojas JC, Karydas A, Bang J, Tsai RM, Blennow K, Liman V, et al. Plasma neurofilament light chain predicts progression in progressive supranuclear palsy. Ann Clin Transl Neurol. 2016;3(3):216-25. 